\title{
NONLINEAR LONGITUDINAL SHEAR DISTRIBUTION IN STEEL-CONCRETE COMPOSITE BEAMS
}

\author{
B. GRZESZYKOWSKI ${ }^{1}$, E. SZMIGIERA ${ }^{2}$
}

\begin{abstract}
This paper describes a fiber-based model proposed for computing the nonlinear longitudinal shear distribution in composite steel-concrete beams. The presented method incorporates the accurate stress-strain relationship with strain softening for concrete and bi-linear constitutive relation for structural steel, both in agreement with Eurocodes, however any one-dimensional constitutive relation can be used. The numerical solution for a simply supported beams loaded with the uniform load, concentrated force and both was presented. The results indicate that the highest value of the shear flow for a beam under an uniform load is at the ends and in the one third of the span length and for the point load, the maximum shear is in the proximity of the concentrated force.
\end{abstract}

Keywords: composite beam, steel, concrete, longitudinal shear, shear flow, fiber element method, non-ductile shear connectors

\section{INTRODUCTION}

In [1] shear connection in composite steel-concrete beams shall be provided to transmit the longitudinal shear force between the concrete and the structural steel element, ignoring the effect of natural bond between both materials and considering an appropriate distribution of design longitudinal shear force. No additional checks on the adequacy of the shear connection are required if the number of shear connectors, distributed between a point of maximum sagging bending moment and an adjacent support, is provided in accordance with the longitudinal shear calculated by elastic theory. However such design is not economical, because the bending moment resistance

\footnotetext{
${ }^{1}$ M.Eng., Warsaw University of Technology, Faculty of Civil Engineering, Al. Armii Ludowej 16, 00-637 Warsaw, Poland, e-mail: bgrz@il.pw.edu.pl

${ }^{2}$ Prof., DSc., PhD., Eng., Warsaw University of Technology, Faculty of Civil Engineering, Al. Armii Ludowej 16, 00-637 Warsaw, Poland, e-mail: e.szmigiera@il.pw.edu.pl
} 
also has to be calculated using elastic theory. The design of composite beams for the ultimate ending momentcapacity gives significant savings in materials consumption. In this paper only beams with full shear connection are considered.

It is possible to apply either an uniform or a non-uniform spacing of shear connectors along the beam designed for the ultimate bending moment resistance $M_{p l, R d}$. To apply the uniform spacing of shear connectors they shall have sufficient deformation capacity (ductility) to justify any inelastic redistribution of the longitudinal shear. According to [1], a connector may be taken as ductile if its characteristic slip capacity is at least $6 \mathrm{~mm}$ (Fig. 1a). But in standard [1] only headed studs with an overall length after welding not less than 4 times the diameter, and with a shank of nominal diameter not less than $16 \mathrm{~mm}$ and not greater than $25 \mathrm{~mm}$ may be considered as ductile, provided that a beam is designed with full shear connection. Where the above rules are not met and an uniform spacing of shear connectors is to be used nevertheless, the design should be based on tests, carried out in a way that provides information on the properties of the shear connection required for design in accordance with standard [1]. Where the shear connectors are used in T-beams with a concrete slab of uniform thickness, standard push-out tests may be used (Fig. 1a). The slip capacity of a specimen should be taken as the maximum slip measured at the characteristic load level. The characteristic slip capacity should be taken as the minimum test value of the slip capacity reduced by $10 \%$ or determined by statistical evaluation from all the test results. If the deviation from the mean exceeds $10 \%$, at least three more tests of the same kind should be made. All the above regulations cause checking whether the shear connectors are ductile enough costly and time consuming.

a)

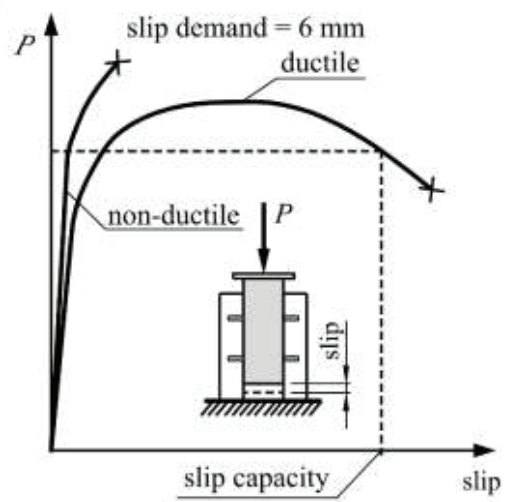

b)

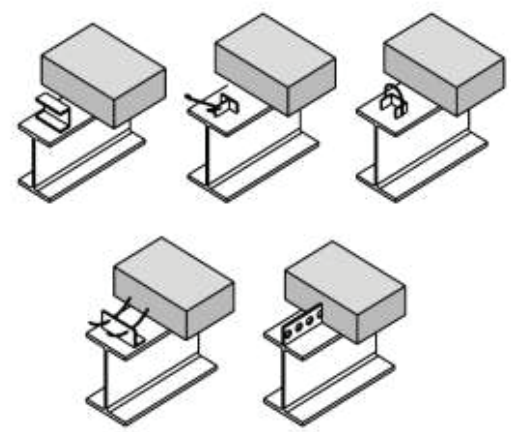

Fig. 1. a) Typical shear strength - slip characteristics for ductile and non-ductile shear connectors,

b) different types of non-ductile shear connectors [2] 
If shear connectors are not proven to be ductile enough or they are rigid (have insignificant deformations in the proximity of ultimate strength), spacing of shear connectors should be adjusted to the nonlinear longitudinal shear distribution computed using non-linear theory [1]. Moreover, for heavy loaded composite beams with substantial longitudinal shear force on the interface of steel and concrete, connectors with very high shear capacity are needed. This may be in a direct contradiction with their ductility and therefore only rigid connectors will have sufficient shear strength (Fig. 1b). Composite dowels are the example of a high-strength shear connectors in steel-concrete composite girders [3], [4]. Compared to headed studs they provide an increased strength but not necessarily (only after meeting certain design conditions) the required deformation capacity. Bending resistance of composite cross-sections with non-ductile shear connectors was the subject of a study in [5]. This paper describes a nonlinear fiber-based model proposed for computing the strain and stress state in composite steel-concrete beams that can be used to determine the nonlinear longitudinal shear distribution on the interface of both materials. The numerical solution for a simply supported beams loaded with uniform load, concentrated force and both is presented.

\section{DESCRIPTION OF THE NUMERICAL ANALYSIS}

\subsection{FIBER ELEMENT METHOD}

Nonlinear fiber based methods have been widely described in the literature in the past. For example in [6] this method was used to analyse the strength of reinforced concrete columns, in [7] and [8] the ultimate bearing capacity of composite steel-concrete columns and in [9] to analyse the behaviour of composite beams. In the fiber element method a composite cross section is discretized into a cluster of fiber elements as shown in Fig. 2. Each fiber element is assigned with material properties appropriate for a given material and represents a theoretical fiber that can deform longitudinally along the beam. It is assumed in this analysis that the slip between steel and concrete does not occur (infinitely rigid connectors) and plane cross-sections remain plane and perpendicular to the centroidal axis after the deformation occurs. Material fibers within the cross sections are subjected to uniaxial stress states and uplift forces are resisted by shear connectors without separation, so the concrete slab and the steel beam deflect equally at every cross section of a beam. Equilibrium of the composite cross section is dependent upon the following equations

$$
N=\int_{A_{c}} \sigma_{c} d A+\int_{A_{s}} \sigma_{s} d A=0
$$




$$
M=\int_{A_{c}} z \sigma_{c} d A+\int_{A_{s}} z \sigma_{s} d A
$$

where $N$ is the resultant axial force equal to 0 in beams under bending only; $M_{R d}$ is the global bending moment resistance of the composite profile; $\sigma_{s}, \sigma_{c}$ are respectively the normal stresses in steel and concrete parts of the cross section and $A_{s}, A_{c}$ are respectively the area of the steel profile and the concrete slab. The discretised version of the force equilibrium equation for the cross section depicted in Fig. 2 can be written as follows

$$
N=b_{c} \Delta h_{c} \sum_{i=1}^{n_{c}} \sigma_{c i}+\sum_{j=1}^{n_{s}} A_{s j} \sigma_{s j}=0
$$

and the moment equilibrium equation is equal

$$
M=b_{c} \Delta h_{c} \sum_{i=1}^{n_{c}} \sigma_{c i} z_{i}+\sum_{j=1}^{n_{s}} A_{s j} \sigma_{s j} z_{j}=0
$$

where $b_{c}$ is the width of the concrete flange, $\Delta h_{c}$ is the thickness of single layer of concrete; $A_{s j}$ is the area of the $\mathrm{j}$-th layer of steel; $\sigma_{s j}, \sigma_{c i}$ denote respectively the normal stresses in $\mathrm{j}$-th steel and $\mathrm{i}$-th concrete part of the cross section and $z_{j}, \mathrm{z}_{i}$ are respectively the distance of the $\mathrm{j}$-th steel and $\mathrm{i}$-th concrete layer from the top of the cross section.

The distribution of the strain in the cross section that satisfies the force equilibrium given by the Eq. (2.3) can be evaluated using as control parameter the strain of the top concrete fibre $\varepsilon_{c t}$. Next the depth of the compression zone $x$ for a given strain and stress distribution in the cross section can be calculated. This step requires an iterative process to solve the non-linear equation (2.3). Subsequently from the Eq. (2.4) the bending moment resistance, as a resultant of the computed stress distribution, can be calculated. Then the calculations should be repeated until the full spectrum of solutions is obtained and the strain in the top fibre reaches the maximum value $\varepsilon_{c t} \leq$ $\varepsilon_{c u 1}$. For $\varepsilon_{c t}=\varepsilon_{c u 1}$ the bending moment resistance is equal to the ultimate bending moment resistance $M_{p l, R d}$. 


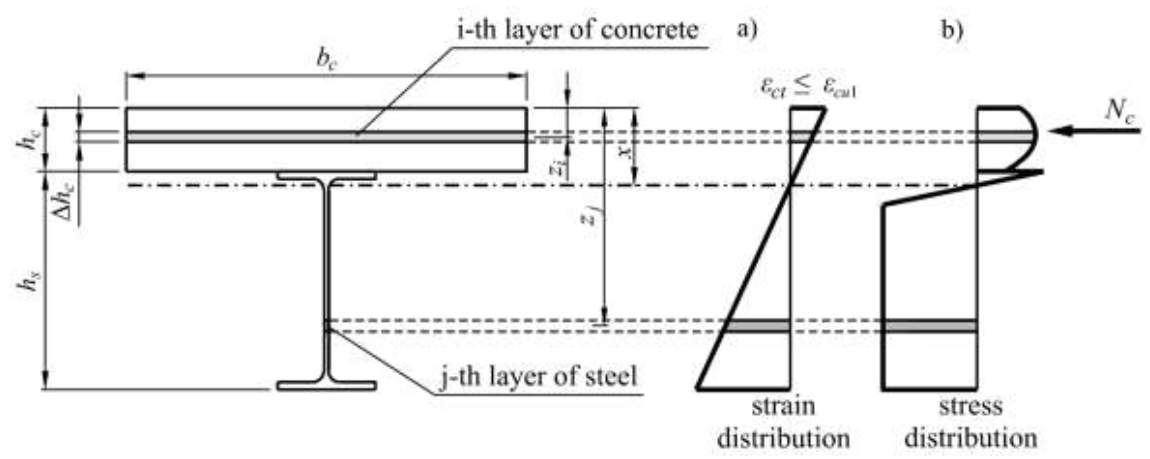

Fig. 2. Distribution of a) strain and b) stress in composite steel-concrete cross section

\subsection{MATERIAL MODELS}

Where the bending resistance of a composite cross section is determined by non-linear theory, according to [1] the stresses in the concrete should be derived from the stress-strain curves given in standard [10]. The stresses in structural steel should be derived from the bi-linear constitutive relationship given in [11] and should take account of the effects of the method of construction (e.g. propped or unpropped beams). It is assumed in this analysis that all beams under consideration are propped. For concrete the nonlinear stress-strain relation with strain softening from standard [10], described by Eqs. $(2.5-2,7)$, was used (Fig. 3a).

$$
\begin{gathered}
\sigma_{c}\left(\varepsilon_{c}\right)=f_{c} \frac{k\left(\frac{\varepsilon_{c}}{\varepsilon_{c 1}}\right)-\left(\frac{\varepsilon_{c}}{\varepsilon_{c 1}}\right)^{2}}{1+(k-2)\left(\frac{\varepsilon_{c}}{\varepsilon_{c 1}}\right)} \\
\varepsilon_{c 1}=0.7 f_{c}^{0.31} \leq 2.8 \\
k=1.05 \varepsilon_{c 1} \frac{E_{c}}{f_{c}}
\end{gathered}
$$

where $f_{c}$ is a cylinder compressive strength of the concrete; $\varepsilon_{c}$ is a concrete strain at a given load level; $\varepsilon_{c 1}$ is the compressive strain at peak stress; $\varepsilon_{c u 1}$ is the crushing strain and $E_{c}$ is the secant modulus of elasticity of concrete. For structural steel the symmetric elastic-perfectly plastic stressstrain relationship without any strain limit indicated in Fig. 3b was used [11]. 
a)

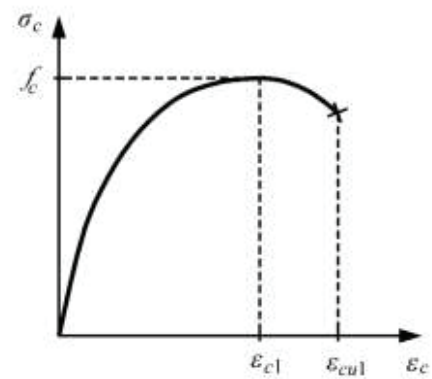

b)

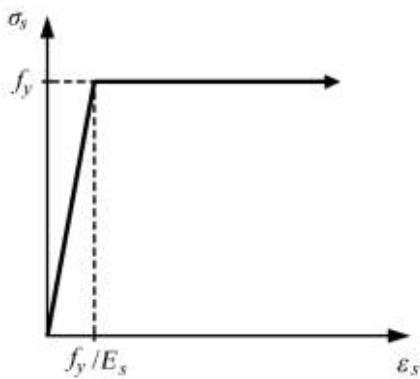

Fig. 3. Assumed in the analysis constitutive relations for a) concrete and b) structural steel

\section{NUMERICAL EXAMPLES}

In Fig. 4a assumed in the analysis composite steel-concrete cross section is presented. The steel beam is made of IPE400 profile and the $150 \times 1750 \mathrm{~mm}$ concrete slab. The total height of the composite beam is $550 \mathrm{~mm}$ and the span length is $10 \mathrm{~m}$. Yield stress of steel is $f_{y}=355 \mathrm{MPa}$, and compressive strength of concrete is $f_{c}=30 \mathrm{MPa}$. The maximum compressive strain for concrete equals to $\varepsilon_{c u 1}=3,5 \%$ [10]. The analysis was carried out for a simply supported beam under uniform (Fig. 4b) and point (Fig. 4c) loading. The maximum load for which the ultimate bending moment resistance of the middle cross section is reached $\left(M(0)=M_{p l, R d}\right)$ equals to $q_{p l}$ in case of uniform loading (Eq. 2.8) and $P_{p l}$ (Eq. 2.9) in case of point loading.

$$
\begin{aligned}
& q_{p l}=8 \frac{M_{p l, R d}}{L^{2}} \\
& P_{p l}=4 \frac{M_{p l, R d}}{L}
\end{aligned}
$$

The maximum bending moment in the middle of the beam is therefore equal to:

$$
M_{\max }=\chi \frac{q_{p l} L^{2}}{8}=\chi \frac{P_{p l} L}{4}=\chi M_{p l, R d}
$$

where $\chi$ is the load multiplier. The nonlinear equations (Eq. (2.3) and (2.4)) were solved using Wolfram Mathematica 10.1 software [12].

Table 1 lists the numerical results of the cross section analysis. The table columns contain, respectively, the load multiplier, $\chi$; the uniform load, $q$; the point load, $P$; and the bending moment 
resistance $M_{R d}$. The ultimate bending moment resistance of the composite cross section is equal to $M_{p l, R d}=958.2 \mathrm{kN} \cdot \mathrm{m}$ (the load multiplier $\chi=1,0$ ) and the elastic resistance to bending, computed for the stress on the bottom of the steel beam being not greater that $f_{y}=355 \mathrm{MPa}$, is equal $M_{e l, R d}=699.5 \mathrm{kN} \cdot \mathrm{m}$. For this value of bending moment the load multiplier is equal to $\chi=699.5$ / $958.2=0.73$.

a)
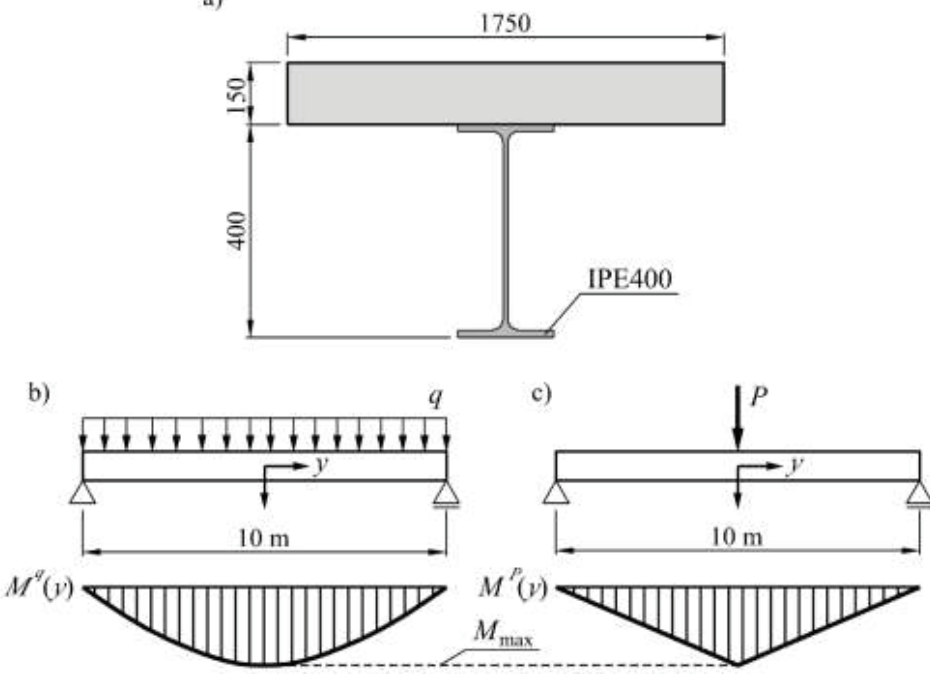

Fig. 4. a) Analysed composite cross section; static scheme of a beam subjected to: a) uniform and b) point loading.

Table 1. Results of the composite cross section analysis

\begin{tabular}{|l|c|c|c|c|}
\hline & $\chi$ & $q$ & $P$ & $M_{\mathrm{Rd}}$ \\
\hline elastic solution & 0.73 & $q_{e l}=56.0 \mathrm{kN} / \mathrm{m}$ & $P_{e l}=279.8 \mathrm{kN}$ & $M_{e l, R d}=699.5 \mathrm{kN} \cdot \mathrm{m}$ \\
\hline plastic solution & 1.0 & $q_{p l}=76.7 \mathrm{kN} / \mathrm{m}$ & $P_{p l}=383.3 \mathrm{kN}$ & $M_{p l, R d}=958.2 \mathrm{kN} \cdot \mathrm{m}$ \\
\hline
\end{tabular}

Fig. 5 and 6 shows the normal stress distributions along the half of a beam for both uniform and point loading respectively for load multipliers $\chi$ equal to 0.73 and 1,0 . The dark orange colour indicates areas where the steel yields, $f_{y}=355 \mathrm{MPa}$. On analysing the data presented in Fig. 5 and 6, it can be concluded that in this example the steel beam is always in tension regardless of the load multiplier, so the depth of the compression zone never exceeds $150 \mathrm{~mm}$. For the load multiplier $\chi=0.73$ the stresses in the entire steel beam are smaller than $f_{y}=355 \mathrm{MPa}$. If the load multiplier increases the plastic zone in the middle bottom part of beams presented in Figs. 5 and 6 starts to appear (dark orange colour) and is growing along with the load multiplier. If the bending moment in 
the middle of the beam reaches its maximum $\left(\chi=1.0, M_{\max }=M_{p l, R d}=958.2 \mathrm{kN} \cdot \mathrm{m}\right)$, the plastic zone spreads over a substantial area of the beam and in the mid-section, the steel yields over the entire height of the profile. For the uniform loading, the shape of the yield zone resembles a parabola and in the case of a concentrated load, it is shaped like a triangle. In the latter the yield area is substantially smaller.
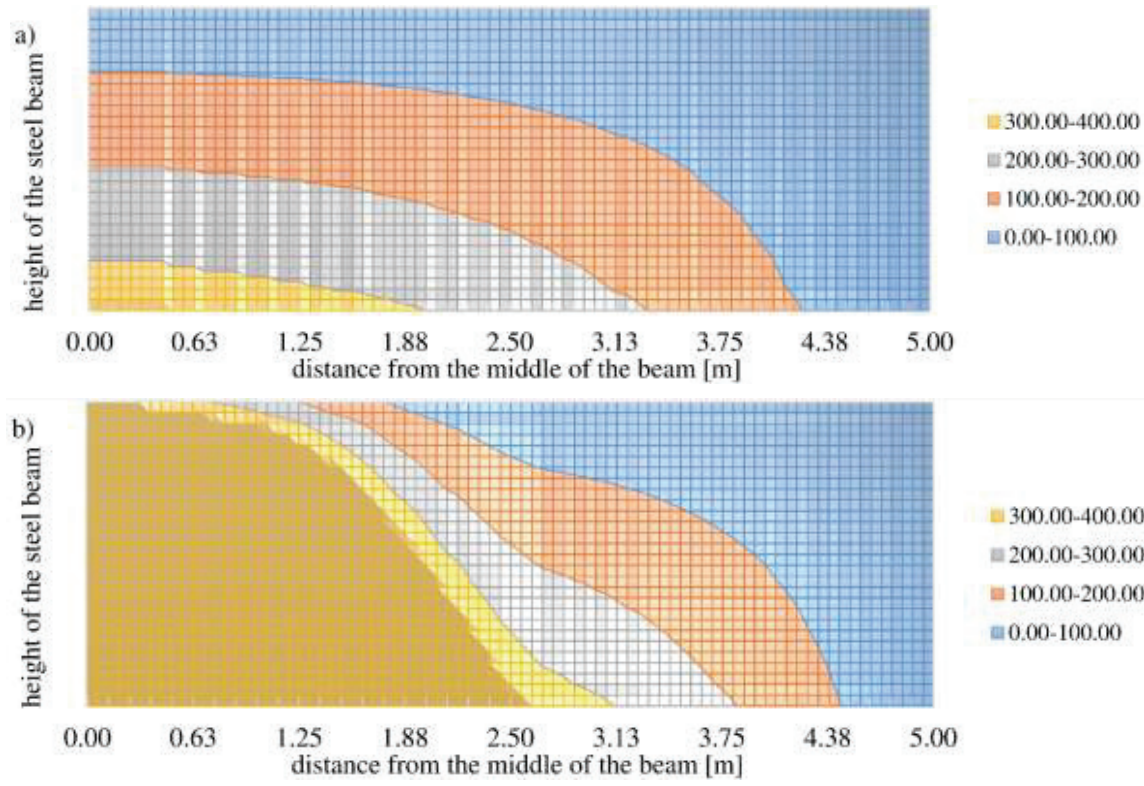

Fig. 5. Normal stress (in MPa) distribution in simply supported beam under uniform loading for load multipliers: a) $\chi=0.73$; b) $\chi=1.0$; half of the span is shown; in dark orange areas $\sigma_{s}=355 \mathrm{MPa}$.

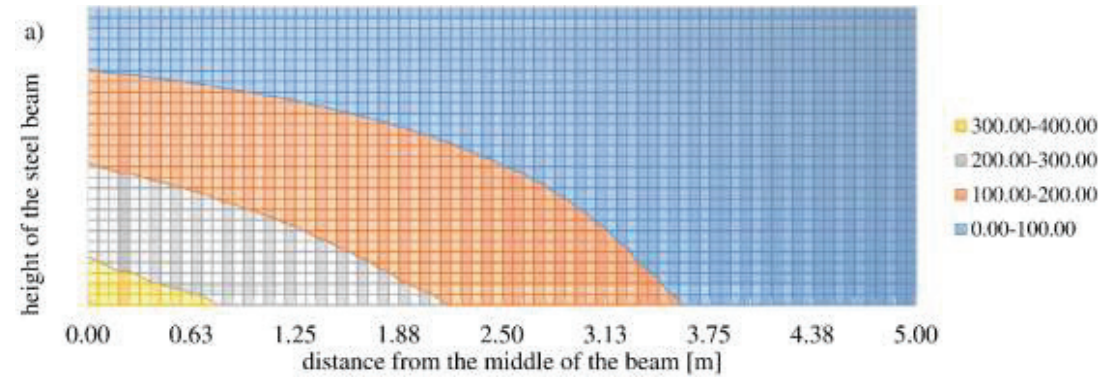




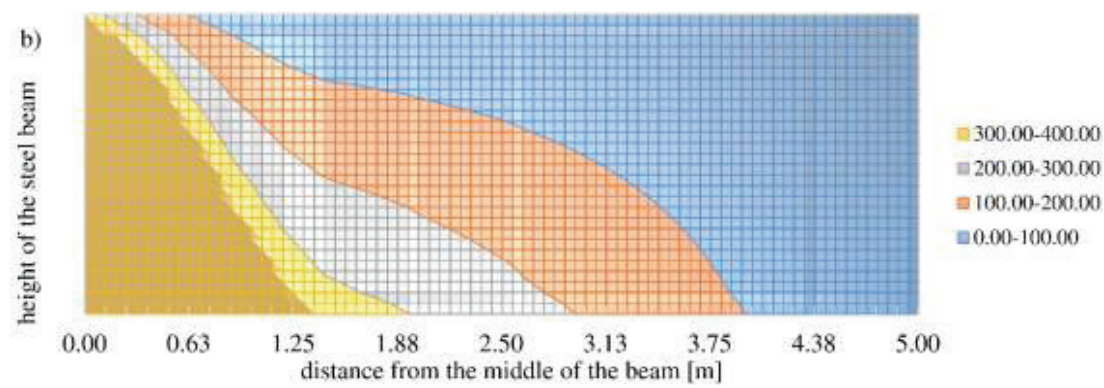

Fig. 6. Normal stress (in MPa) distribution in simply supported beam under point loading for load multipliers: a) $\chi=0.73$; b) $\chi=1.0$; half of the span is shown; in dark orange areas $\sigma_{s}=355 \mathrm{MPa}$.

According to [1], the total design longitudinal shear shall be determined in a manner consistent with the design bending resistance, taking account of the difference in the normal force in concrete or structural steel over a critical length. Due to sagging bending moment the compressive stress in the concrete slab arise. The resultant of this stress is the compressive force $N_{c}$ which causes the delamination of steel and concrete on the interface of both materials. The resultant compressive force in the concrete slab $N_{c}$ can be computed from the following expression

$$
N_{c}=b_{c} \int_{0}^{\min \left(x, h_{c}\right)} \sigma_{c}(x) d x
$$

where $x$ is the depth of the compression zone calculated using Eq. (2.3). The relation between the bending moment and the resultant compressive force in the concrete slab computed for the crosssection shown in Fig. 4 is depicted in Fig. 7.

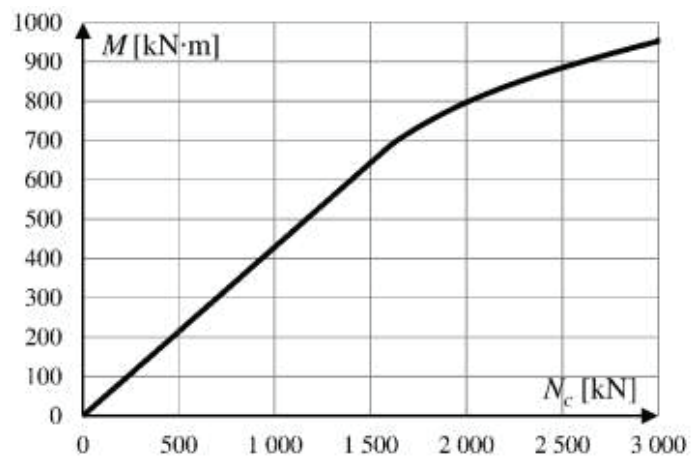

Fig. 7. The relationship between bending moment and resultant compressive force in the concrete slab 
The difference between $N_{c}$ forces in two critical cross sections of a beam will be called the resultant longitudinal shear force $V_{l, E d}$. Shear connectors are designed to counteract this force and prevent the delamination. The resistance to longitudinal shear should be checked at a critical length between the two sections, which includes sections of maximum bending moments, supports, sections subjected to concentrated loads or reactions and places where sudden change of cross section occurs, other than a change due to cracking of concrete. In case of a simply supported beam presented in Fig. $4 \mathrm{~b}$ and c, the critical length is equal to the half of the span length $L / 2$ and the resultant longitudinal shear force at a cross section at a distance $y$ from the centre of a beam $V_{l, E d}(y)$ can be computed as follows:

$$
V_{l, E d}(y)=N_{c}(y)-N_{c}(L / 2)=N_{c}(y)-0=N_{c}(y)
$$

Knowing the $M-N_{c}$ relation (Fig. 7), bending moment diagram (Fig $4 \mathrm{~b}$ and c) and using the Eq. (2.12) the distribution of $V_{l, E d}$ along the span of a beam can be computed numerically. The derivative of $V_{l, E d}$ over the length of the beam:

$$
T_{l, E d}(y)=\frac{d V_{l, E d}(y)}{d y}
$$

is the longitudinal shear force per unit length, otherwise known as the shear flow. The above equation can be used even for $M_{\max } \geq M_{e l, R d}$. If it is assumed that the composite beam acts in an elastic manner $\left(M_{\max } \leq M_{e l, R d}\right)$ then the shear flow can be calculated from the well-known equation:

$$
T_{l, E d}(y)=\frac{S}{J} V_{E d}(y)
$$

where $S$ stands for the first moment of area of either the concrete slab or the steel section about the elastic neutral axis of the composite cross section; $J$ is the second moment of area of the composite cross section, $V_{E d}(y)$ is the vertical shear force distribution along the span of the beam. The results obtained using Eq. (2.13) and (2.14) for $M_{\max } \leq M_{e l, R d}$ will be identical.

In Figs. $8 \mathrm{a}$ and $\mathrm{b}$ the distribution of the resultant shear force $V_{l, E d}$ and the longitudinal shear force per unit length $T_{l, E d}$ for a simply supported beam under uniform load for various load multipliers $\chi$ is presented. In Figs. 9a and $\mathrm{b}$ the $V_{l, E d}$ and $T_{l, E d}$ distributions for a beam under point load in the mid-span is presented. On analysing the data presented in Figs. 8 and 9 it can be concluded that for the load multiplier $\chi$ the solution coincides with the linear distribution of the longitudinal shear. With the increase of the load multiplier, the solution starts to deviate from linearity. In the case of the uniform load (Fig. 8), the deviation occurs approximately in one third of 
the span length and in case of the point load, in the close proximity to the concentrated force. . In general the solution is nonlinear in areas of the span where $M>M_{e l, R d}$. The value of the shear flow $T_{l, E d}$ in the mid-span, due to symmetrical boundary and loading conditions, should be equal to zero. This is the case for a uniform load (Fig. 8), but directly under the concentrated force a numerical singularity occurs and in the nearest proximity of the force the shear flow was of its maximum value. In fact in the real structures the area of the load application is always finite, especially because the force is usually applied at the top of the slab with a vertical distance to the centroidal axis of the beam. Therefore in Fig. $9 b$ the shear flow diagrams were slightly adjusted near the point load, just to intersect at zero in the mid-span. )

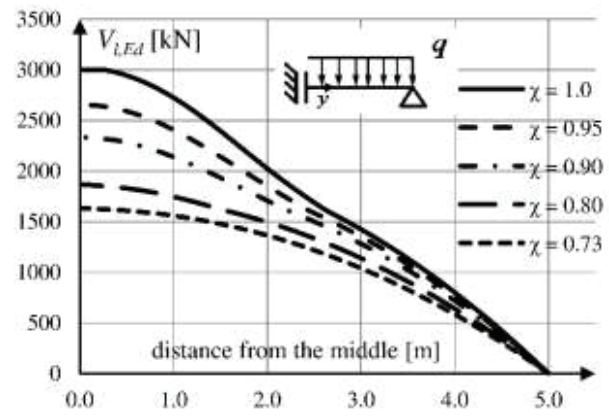

b)

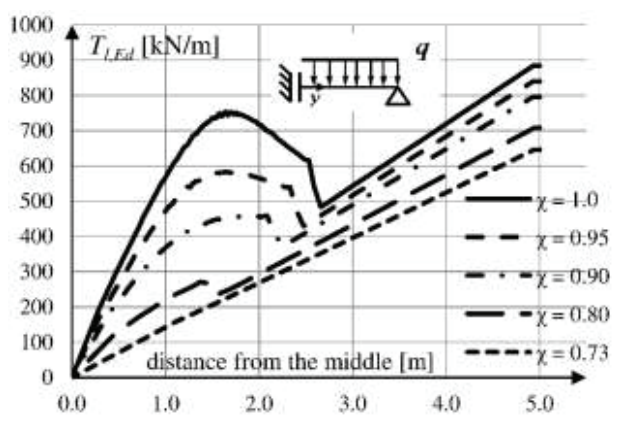

Fig. 8. Distribution of a) $V_{E d}$ and b) $T_{E d}$ in a simply supported beam under uniform load for various load multipliers $\chi$; half of the span is shown.

a)

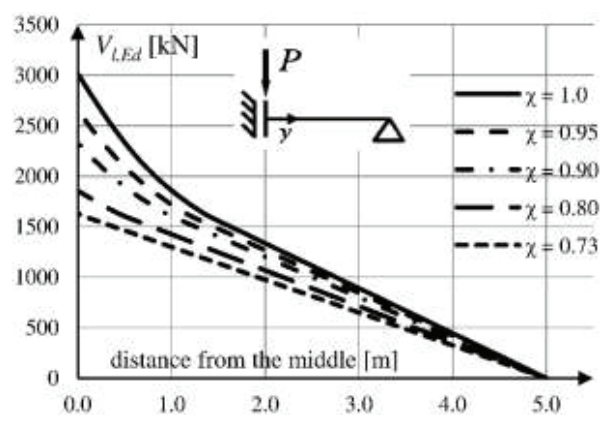

b)

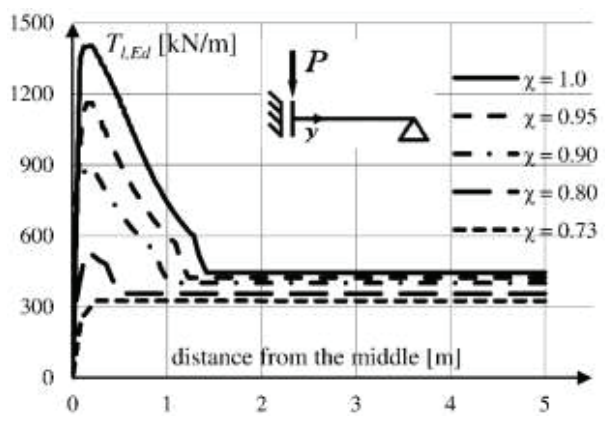

Fig. 9. Distribution of a) $V_{E d}$ and b) $T_{E d}$ in a simply supported beam under point load in the mid-span for various load multipliers $\chi$; half of the span is shown.

In Fig. 10 the additional static scheme of a simply supported beam subjected to both the uniform and point load was presented. A simply supported beam is a statically determinate 
structure, therefore even in the non-linear analysis the maximum bending moment in the middle of the beam equals to the sum of bending moments from the loads $q$ and $P$ :

$$
M_{\max }^{q+P}=\lambda M_{\max }^{q_{p l}}+(1-\lambda) M_{\max }^{P_{p l}}=\lambda \frac{q_{p l} L^{2}}{8}+(1-\lambda) \frac{P_{p l} L}{4}=M_{p l, R d}
$$

where $\lambda$ is the load quotient parameter which determines the participation of the uniform and point load in the total load; for $\lambda=1.0, q=q_{p l}$ and $P=0$; for $\lambda=0, q=0$ and $P=P_{p l}$.

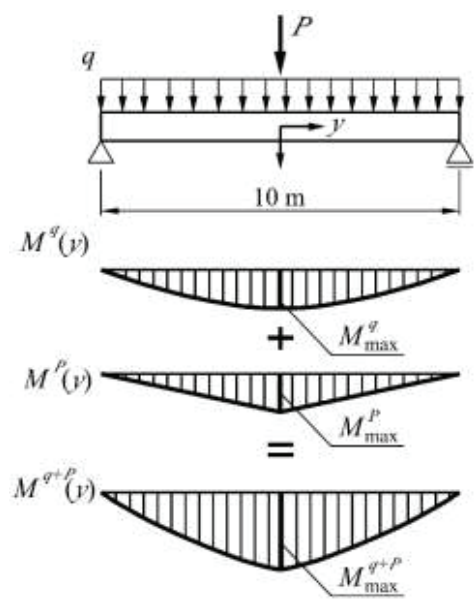

Fig. 10. Bending moment diagrams for a simply supported beam subjected to both uniform and point load

In Fig. 11 the distribution of the resultant shear force $V_{l, E d}$ and the shear flow $T_{l, E d}$ for a beam from Fig. 10 for various load quotient parameters $\lambda$ is presented. On analysing the data presented in Fig. 11 it can be concluded that in the areas close to the beam's end, where the linear solution is in effect, the superposition rule holds. In other regions, closer to the mid-span, the solution is highly non-linear. At the beam's ends, the highest value of $T_{l, E d}$ is obtained for $\lambda=1.0$ and in the mid-span for $\lambda=0$. It seems interesting that the lowest value of the maximum longitudinal shear flow $T_{l, E d}$ obtained for $\lambda \approx 0.25$ is in one third of the span (Fig. 11b). Introducing a relatively small additional point load into the beam loaded with the uniform load (as $P$ increases $q$ is being reduced for the maximum bending moment to remain equal $M_{\max }=M_{p l, R d}$ ) can actually reduce the total longitudinal shear flow.

In Fig. 12 the distribution of the acting shear force per unit length $T_{l, E d}$ and the longitudinal shear capacity per unit length $T_{l, R d}$ (longitudinal shear strength) for a simply supported beam under both uniform (Fig. 12a) and point loading (Fig. 12b) was presented. The shear flow capacity $T_{l, R d}$, 
assuming an uniform spacing of shear connectors according to [1], is constant and in this example equals to $T_{l, R d}=600 \mathrm{kN} / \mathrm{m}$. The resultant longitudinal shear capacity $V_{l, R d}$ is therefore equal to $V_{l, R d}=T_{l, R d} L / 2=600.5=3000 \mathrm{kN}$. In this work the connection on the interface of steel and concrete is assumed to be infinitely rigid - the slip between the concrete slab and the steel beam is therefore equal to zero along the entire beam. Therefore in areas, where $T_{l, E d}$ is greater than $T_{l, R d}$, the plastic redistribution of the longitudinal shear flow will occur, provided the ductile shear connectors are used. Owing to the high deformability (Fig. 1a) ductile shear connectors deform adopting to the rectangular shear flow capacity $T_{l, R d}$. The slip between steel and concrete occurs but has no significant effect on the bending moment capacity of the composite beam [9].

a)

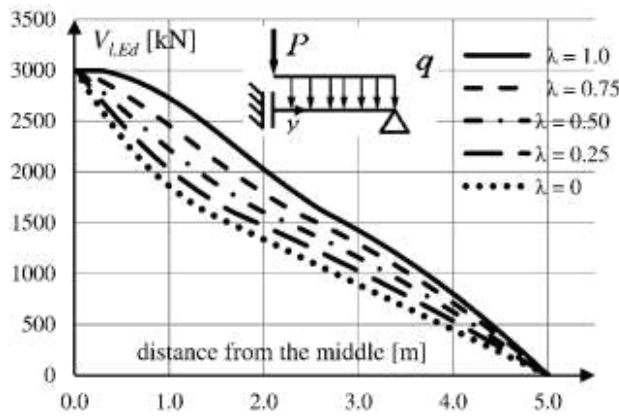

b)

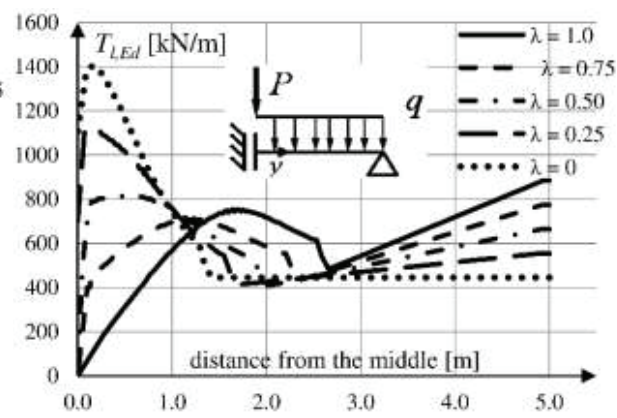

Fig. 11. Distribution of a) $V_{E d}$ and b) $T_{E d}$ in a simply supported beam under both uniform and point load for different load quotients $\lambda$; half of the span is shown.

a)

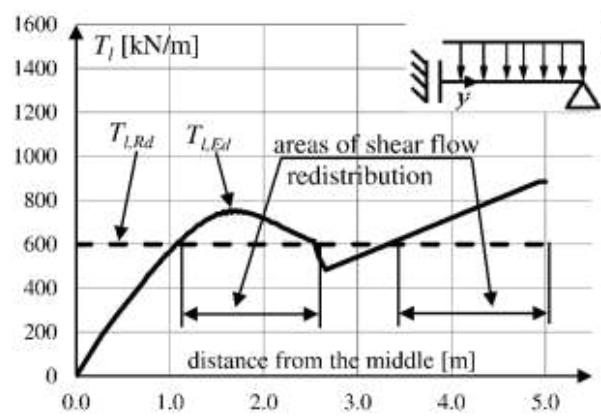

b)

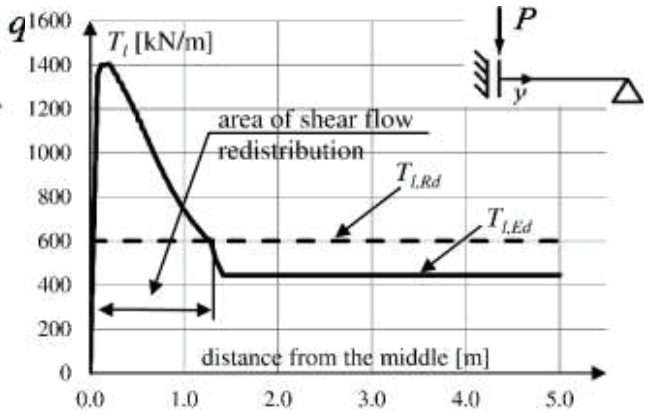

Fig. 12. Redistribution of the longitudinal shear flow for uniform spacing of ductile connectors for the simply supported beam under a) uniform and b) point loading. 
On analysing the data presented in Fig. 12b it can be concluded that in the middle of the beam, the longitudinal shear flow $T_{l, E d}$ is over two times higher than the shear capacity $T_{l, R d}$. The difference between $T_{l, E d}$ and $T_{l, R d}$ is almost three times greater in case of the beam subjected to the point load in comparison to the uniform load. This may prevent the shear redistribution in areas in close proximity to the substantial concentrated forces and increase the slip demand of shear connectors in those areas. A confirmation of this observation can be found in [13], where beams with the different connector rigidities but the same ultimate load capacity have been analysed. Two types of loading were considered: a central point load $P$ and uniformly distributed load $q$. For uniformly distributed loading the value of the maximum load were nearly identical for both rigid and flexible connections. In case of beams under point loading, there was a $10 \%$ loss in the ultimate bearing capacity of the beams with flexible connectors in comparison to rigid ones. The solution to this may be to strengthen areas surrounding the substantial concentrated forces. Nevertheless it is worth noting that such case in which the concentrated force loading is predominant over the uniform load may rarely occur (e.g. beams supporting columns or high technological load).

\section{CONCLUSIONS}

The study described in this paper was conducted to simulate the behaviour of composite steelconcrete beams with non-ductile, rigid shear connectors. An attempt was made to explain the paradox present in composite steel concrete beams in which for rigid shear connectors the shear flow computed using vertical shear force distribution (the statics) is not consistent with the longitudinal shear computed using the cross section resistance. A nonlinear fiber-based model was used to determine the nonlinear longitudinal shear distribution on the interface of both materials. The presented model incorporates the elastic-perfectly plastic constitutive relation for structural steel and the stress-strain relationship with strain softening for concrete, both in the agreement with Eurocodes. The numerical solution for a simply supported beams loaded with the uniform load, concentrated force in the mid-span and the combination of both was presented.

The results of this study indicate that the highest value of the shear flow for the uniform load is at the beam's ends and in the one third of the span length. For the point load, the maximum shear is in the mid-span in the direct proximity of the concentrated force. The nonlinear behaviour occurs in areas of the beam where the bending moments exceeds the elastic elastic resistance to bending of the composite cross-section. The interesting fact is that introducing additional concentrated force load of a relatively small value, $\lambda \approx 0.25$, in the mid-span of the beam already loaded with the 
uniform load (assuming that the maximum bending moment in the middle of the beam is equal $M_{\max }=M_{p l, R d}$ ) will reduce the total longitudinal shear flow. Moreover in beams loaded with a substantial point load without any significant uniform loading, the shear flow in close proximity of the concentrated force can be very high. This may cause an increase in the strength demand of shear connectors in those areas. The calculation method presented in this article can be used to design high-strength non-ductile shear connectors in composite steel-concrete beams under heavy loading.

\section{REFERENCES}

1. CEN, EN 1994-1-1:2008 - Eurocode 4: Design of composite steel and concrete structures - Part 1-1: General rules and rules for buildings. 2008 .

2. E. Szmigiera, M. Niedośpiał, B. Grzeszykowski, "Projektowanie konstrukcji zespolonych stalowobetonowych, część 1, elementy zginane", PWN, Warsaw, Poland, 2019.

3. W. Lorenc, "Boundary approach in shape study of composite dowel shear connector", Archives of Civil and Mechanical Engineering, 9(4): pp 55-66, 2009.

4. M. Kopp, K. Wolters, M. Claßen, J. Hegger, M. Gündel, J. Gallwoszus, S. Heinemeyer, M. Feldmann, "Composite dowels as shear connectors for composite beams-background to the design concept for static loading", Journal of Constructional Steel Research, 147: pp 488-503, 2018.

5. S. Kostic, B. Deretic-Stojanovic, "Bending resistance of composite sections with nonductile shear connectors and partial shear connection", Advances in Civil Engineering, 2018.

6. S. A. Mahin, V.V. Bertero, RCCOLA, "a Computer Program for Reinforced Concrete Column Analysis: User's Manual and Documentation", Department of Civil Engineering, University of California, 1977.

7. S.A. Mirza, B. W. Skrabek, "Reliability of short composite beam-column strength interaction", Journal of Structural Engineering, 117(8): pp 2320-2339, 1991.

8. S. El-Tawil, C. F. Sanz-Picon, G. G. Deierlein, "Evaluation of ACI 318 and AISC (LRFD) strength provisions for composite beam-columns", Journal of Constructional Steel Research, 34(1): pp 103-123, 1995.

9. J. Rotter, P. Ansourian, "Cross-section behaviour and ductility in composite beams", 1978.

10. CEN, EN 1992-1-1:2008 - Eurocode 2: Design of concrete structures - Part 1-1 : General rules and rules for buildings. 2008.

11. CEN, EN 1993-1-1:2006 - Eurocode 3: Design of steel structures - Part 1-1: General rules and rules for buildings. 2006.

12. Wolfram Research Inc., Mathematica 10.1, Champaign, Illinois, 2015.

13. L. C. P. Yam, J. C. Chapman, "The inelastic behaviour of simply supported composite beams of steel and concrete", Proceedings of the institution of civil engineers, 41(4): pp 651-683, 1968. 


\section{LIST OF FIGURES AND TABLES:}

Fig. 1. a) Typical shear strength - slip characteristics for ductile and non-ductile shear connectors, b) different types of no-ductile shear connectors [2]

Rys. 1. a) Typowa zależność nośność na ścinanie - poślizg dla ciągliwych i nieciągliwych łączników na ścinanie, b) różne typy nieciągliwych łączników na ścinanie

Fig. 2. Distribution of a) strain and b) stress in composite steel-concrete cross section

Rys. 2. Rozkład a) odkształceń i b) naprężeń w stalowo-betonowym przekroju zespolonym

Fig. 3. Assumed in the analysis constitutive relations for a) concrete and b) structural steel

Rys. 3. Przyjęte w analizie relacje konstytutywne dla a) betonu i b) stali kształtownika

Fig. 4. a) Analysed composite cross section; static scheme of a beam subjected to: a) uniform and b) point loading.

Rys. 4. a) Analizowany przekrój zespolony; schemat statyczny belki obciążanej: a) równomiernie i b) siłą skupioną

Fig. 5. Normal stress (in MPa) distribution in simply supported beam under uniform loading for load multipliers: a) $\chi=0.73$; b) $\chi=1.0$; half of the span is shown; in dark orange areas $\sigma_{s}=355 \mathrm{MPa}$.

Rys. 5. Rozkład naprężeń normalnych (w MPa) w belce swobodnie podpartej obciążonej równomiernie dla różnych mnożników obciążenia: a) $\chi=0.73$; b) $\chi=1.0$; pokazano połowę przęsła; w obszarach ciemnopomarańczowych $\sigma_{s}=355 \mathrm{MPa}$.

Fig. 6. Normal stress distribution (in MPa) in simply supported beam under point loading for load multipliers: a) $\chi=0.73$; b) $\chi=1.0$; half of the span is shown; in dark orange areas $\sigma_{s}=355 \mathrm{MPa}$. Rys. 6. Rozkład naprężeń normalnych (w MPa) w belce swobodnie podpartej obciążonej siłą skupioną dla różnych mnożników obciążenia: a) $\chi=0.73$; b) $\chi=1.0$; pokazano połowę przęsła; w obszarach ciemnopomarańczowych $\sigma_{s}=355 \mathrm{MPa}$.

Fig. 7. The relationship between bending moment and resultant compressive force in the concrete slab Rys. 7. Zależność między momentem zginającym a wypadkową siłą ściskającą w płycie betonowej Fig. 8. Distribution of a) $V_{E d}$ and b) $T_{E d}$ in a simply supported beam under uniform load for various load multipliers $\chi$; half of the span is shown.

Rys. 8.Rozkład a) $V_{E d}$ i b) $T_{E d}$ w belce swobodnie podpartej obciążonej równomiernie dla różnych mnożników obciążenia $\chi$, pokazano połowę przęsła.

Fig. 9. Distribution of a) $V_{E d}$ and b) $T_{E d}$ in a simply supported beam under point load in the mid-span for various load multipliers $\chi$; half of the span is shown.

Rys. 9. Rozkład a) $V_{E d}$ i b) $T_{E d}$ w belce swobodnie podpartej obciążonej siłą skupioną dla różnych mnożników obciążenia $\chi$, pokazano połowę przęsła.

Fig. 10 Bending moment diagrams for a simply supported beam subjected to both uniform and point load. Rys. 10.Wykresy momentów zginających w belce swobodnie podpartej obciążonej równomiernie i siłą skupioną. 
Fig. 11. Distribution of a) $V_{E d}$ and b) $T_{E d}$ in a simply supported beam under both uniform and point load for different load quotients $\lambda$; half of the span is shown.

Rys. 11. Rozkład a) $V_{E d}$ i b) $T_{E d}$ w belce swobodnie podpartej obciążonej równomiernie i siłą skupioną, dla różnych stosunków obciążenia $\lambda$, pokazano połowę przęsła.

Fig. 12. Redistribution of the longitudinal shear flow for uniform spacing of ductile connectors for the simply supported beam under a) uniform and b) point loading.

Rys. 12. Redystrybucja ścinania podłużnego przy równomiernym rozmieszczeniu ciągliwych łączników na ścinanie dla belki swobodnie podpartej obciążonej a) równomiernie oraz b) siłą skupioną.

Table 1. Results of the composite cross section analysis; Table 1. Wyniki analizy przekroju zespolonego 


\section{NIELINIOWY ROZKŁAD ŚCINANIA PODŁUŻNEGO W STALOWO-BETONOWYCH BELKACH ZESPOLONYCH}

Slowa kluczowe: belka zespolona, stal, beton, podłuże ścinanie, fiber element method, nieciągliwe łączniki na ścinanie

\section{STRESZCZENIE:}

Równomierny rozstaw łączników na ścinanie w stalowo-betonowych belkach zespolonych według Eurokodu 4 można zastosować tylko dla ciągliwych łączników ścinanych, w których charakterystyczna zdolność do poślizgu wynosi co najmniej $6 \mathrm{~mm}$. Według normy EC4 tylko łączniki sworzniowe z łbami o całkowitej długości po przyspawaniu nie mniejszej niż 4-krotna średnica i z trzpieniem o nominalnej średnicy nie mniejszej niż $16 \mathrm{~mm}$ i nie większej niż $25 \mathrm{~mm}$ można uznać, że spełniają powyższy warunek. W związku z tym stosowanie innych typów łączników rozmieszczonych równomiernie na długości krytycznej belki jest możliwe tylko na podstawie badań eksperymentalnych. Dodatkowo, w belkach poddanych dużym obciążeniom, w których podłużna siła ścinająca osiąga duże wartości, należy stosować łączniki ścinane charakteryzujące się znaczną nośnością. W tego typu łącznikach trudne może być spełnienie warunku ciągliwości, przy jednoczesnym zachowaniu wymaganej nośności na ścinanie.

Według Eurokodu 4 łączniki ścinane można rozmieścić na długości krytycznej belki zgodnie z rozkładem ścinania obliczonym za pomocą teorii sprężystości. Jednakże nośność sprężysta przekroju zespolonego (klasy 1 i 2) jest znacznie mniejsza od jego nośności granicznej, co powoduje zwiększenie zużycia materiałów. Aby tego uniknąć i wykorzystać plastyczne rezerwy nośności przekroju zespolonego, rozkład podłużnej siły ścinającej należy obliczyć za pomocą teorii nieliniowej.

W artykule przedstawiono procedurę wyznaczania nieliniowego rozkładu ścinania podłużnego w belkach zespolonych za pomocą „Fiber Element Method”. Podano rozwiązania numeryczne dla belki swobodnie podpartej obciążonej równomiernie, siłą skupioną w środku rozpiętości oraz obydwoma obciążeniami jednocześnie.

W wyniku przeprowadzonych analiz stwierdzono, że dla momentów zginających większych od sprężystej nośności na zginanie przekroju zespolonego, występuje nieliniowy wzrost jednostkowej podłużnej siły ścinającej. W przypadku belki obciążonej równomiernie ścinanie podłużne wzrasta nieliniowo w ok. 1/3 rozpiętości belki, a w przypadku belki obciążonej siłą skupioną bezpośrednio pod siłą skupioną. Interesujący wydaje się fakt, że wprowadzenie punktowego obciążenia o niewielkiej wartości do belki poddanej obciążeniu równomiernemu (przy założeniu nieprzekroczenia nośności plastycznej belki w środku przęsła) może spowodować spadek jednostkowej siły ścinającej w okolicy środka belki. Ponadto w belkach obciążonych znacznymi siłami skupionymi, w których obciążenie punktowe stanowi przeważającą część całkowitego obciążenia, jednostkowa siła ścinająca w okolicy punktu przyłożenia siły skupionej, otrzymana $\mathrm{z}$ analizy nieliniowej, może być znaczna. Może to powodować potrzebę dozbrojenia połączenia na ścinanie dodatkowymi łącznikami w bezpośrednim sąsiedztwie dużych sił skupionych. 